\title{
Politics, Industrialization and Citizenship: Unemployment Policy in England, France and the United States, 1890-1950*
}

\author{
MIRIAM COHEN AND MICHAEL HANAGAN
}

With the "forward march of labor halted", and labor movements everywhere in retreat, T.H. Marshall's state-based emphasis on social welfare as "social right" has reminded those interested in reform that appeals to membership in a national community, the essence of citizenship, have served to rally groups to successful struggles for reform. Those aspects of Marshall's ideas, best summarized in his classic 1949 address, "Citizenship and Social Class", with the greatest resonance for modern social theorists revolve around the relationship between citizenship, rights and markets. For Marshall, "the universal status of citizenship" was a plane of equality such that "all who possess the status (of citizenship) are equal with respect to the rights and duties with which the status is endowed". ${ }^{1}$ Rights were embodied in a common culture and enforced by state power. Marshall believed that, gradually, one particular kind of rights, "social rights", would come to limit the power of the market. While markets would continue to exist and to generate social inequality, government redistribution would increasingly expand the plane of equality to include the most important aspects of material and cultural life. The distinctive feature of these social rights according to Marshall is that they were not exemptions, privileges or paternalistic solicitude for those excluded from what he labels the "national community", but social rights were benefits given to members of the community to encourage and facilitate their continued participation. ${ }^{2}$

Important elements in Marshall's argument and the focus of this paper are Marshall's assertions that social rights: (1) resulted from universal suffrage; (2) developed as a consequence of a new sense of social solidarity kindled by the expansion of political rights; and (3) restricted markets.

We agree that the possession of one particular type of political right, the suffrage, encouraged the widespread adoption of the political rhetoric

\footnotetext{
* We would like to thank Carmenza Gallo, Clyde Griffen, Chris Johnson, Tony Pereira and Charles Tilly for their helpful comments on this paper. We would also like to thank the participants in the Proseminar on State Formation at the New School for Social Research, 1993-1994, for their comments. An earlier version of this paper was presented at the North American Labor History Conference, October 1993.

'T.H. Marshall, "Citizenship and Social Class", in Marshall, Citizenship and Social Class and Other Essays (Cambridge, 1950), pp. 1-85, 28-29.

2 J.M. Barbalet, Citizenship (Minneapolis, 1988), p. 69.
} 
of citizenship. The language of "right" and "citizen" became the typical form of claim-making in democratic societies. But we doubt that the language of citizenship entrained social policy in one definite direction. Granted, in the case of industrial workers, universal suffrage encouraged the advance towards social rights in so far as it increased the political resources of a formerly disenfranchised group strongly affected by market fluctuations. While political rights could promote the development of doctrines of social solidarity, they were also compatible with political individualism. And battles over suffrage could create enduring political divisions that inhibited the development of social rights.

Marshall's nearly exclusive attention to social citizenship and social solidarity limited his appreciation of rival political and moral claims and the persistence of conflicts within democratic societies. His failure to sketch out the relationship between universal moral entitlements and state-based commitments to partial entitlements meant that he could provide very little basis for understanding how conflicts among rights are resolved. ${ }^{3}$ Marshall was keenly aware of the limitations to social policy coverage in his society and hoped to overcome these limitations by the extension of coverage, but he was less attentive to the qualitative limitations of social policy. The extension of wage-based social insurance to all workers, for example, consistently benefited male wage-earners more than most women, who participated erratically in industry. Given existing programs dependent on accumulated contributions, whose justification was based on the rights of paid workers, how to provide equal benefits for women? Instead of confronting the issues of conflicting rights, Marshall mixed all kinds of rights together indiscriminately, more or less assuming their mutual compatibility. In one of his later essays, he remarks that "[...] when I speak of rights, I include everything from legal rights, through social rights to moral rights [. . .]". ${ }^{4}$ Marshall's conviction that political order was based on moral consensus led him consistently to ignore the moral justifications actually employed by popular movements. While almost all political movements used the rhetoric of citizenship in the national political arena, they often used other, non-rights-based justifications in mobilizing their constituencies. As we shall show, rights-based popular movements were only one kind of organized group that built welfare states.

Marshall's elision of the distinction between moral and legal rights is closely related to his belief that "rights are not a matter for bargaining".s

${ }^{3}$ By contrast, David Montgomery has recently-shown how rights of citizen workers in nineteenth-century America were ultimately undermined by the unbridled rights exercised by American employers. Citizen Worker: The Experience of Workers in the United States with Democracy and the Free Market during the Nineteenth Century (New York, 1993).

'T.H. Marshall, "The Right to Welfare", in Marshall, The Right to Welfare and Other Essay's (London, 1981), pp. 83-103, 83.

s Marshall, "Citizenship and Social Class", p. 69. This problem is raised by Anthony Giddens, "Class Division, Class Conflict and Citizenship Rights", in Giddens, Profiles and 
Although differing in their policy applications, the outlines of Marshall's arguments were adopted from the Oxford philosopher, T.H. Green and the English neo-Hegelian idealists, and from the English "New Liberals", influenced by Green, such as L.T. Hobhouse and William Beveridge. Fundamentally, like the neo-Hegelian idealists, Marshall saw the state as a moral agency devoted to achieving the common good. Like the New Liberals, he believed that the recognition of basic human equality implied by suffrage extension could serve as a basis for moral appeals to an enormous extension of welfare state entitlements. ${ }^{6}$ Thus, he had little room for viewing rights as political outcomes of social conflict and negotiation among antagonistic organized groups.

For Marshall, the growth of the modern welfare state is a direct product of the growth of a moral consensus within individual countries about social entitlement and social needs. We believe that these rights are less a product of a sense of moral community, rather they emerge because of political division, social mobilization and the breakdown of existing political arrangements. Welfare legislation and social entitlements came as a result of prolonged negotiations among a variety of social and political groups, each seeking to reestablish political order, but on a new basis. The give and take of bargaining on specific measures by groups of very different political persuasions and moral perspectives was key to the creation of the modern welfare state.

Marshall was too vague about the relationship between the sphere of markets and the sphere of social rights. He emphasized the extent to which social rights restricted markets, but he neglected to stress the degree in which they reinforced and reinvigorated them. Marshall viewed markets as concerned with production and social rights as dealing with redistribution; social rights counteracted the inherent inequality of markets. As we shall show, in the case of unemployment, conflicts over social rights were fought out among groups that sought to restructure markets in order to affect the character of production. Questions of citizenship and citizenship rights were intimately connected to labor supply, labor mobility, immigration and emigration. Marshall saw the goal of the welfare state as the "general enhancement of the concrete substance of civilized life", but the very generality of this purpose provides little insight into why certain issues come to the forefront in social conflict in different periods. A focus on labor market conditions helps explain the salience of battles over unemployment in England and the United States in contrast with France in the years between 1870 and 1950. And further attention to labor markets helps us understand

Critiques in Social Theory (London, 1982), pp. 164-180 and Charles Tilly, "Where Do Rights Come From?", Working Paper, no. 98 (July 1990), Center for Studies of Social Change.

6 Cited in Andrew Vincent and Raymond Plant, Philosophy, Politics and Citizenship: The Life and Thought of the British Idealists (Oxford, 1984), p. 30. 
the kind of social rights that came to dominate in different industrial nations and why differences in the character of social rights have developed and endured in individual states.

To explore these issues, the paper looks at the relationship between the expansion of suffrage and social rights in England, France and the United States in the years between 1870 and 1950; specifically, it examines the question of the expansion of unemployment benefits. It investigates the extent to which the expansion of suffrage provided the axis for building a universalistic unemployment policy. A particular focus is labor migration because the character and extent of migration was an excellent indicator of the overall conditions of the labor market in individual nations and because the situation of migrants poses a considerable challenge to theorists of citizenship. Migrants, after all, are the group most peripheral to any conception of social obligation based on membership in the national community. Moreover, as. we shall show, in all three countries, the evolution of unemployment benefits was linked to issues of immigration and both were issues of foremost concern to employers as well as to organized workers.

Organized into three separate sections, the paper first discusses the relationship between markets and citizenship and shows that the condition of labor markets strongly influenced the nature of debate and the outcomes in the field of unemployment policy. Second, it explores the connection between political rights and social rights. Here, we maintain that political rights, seen as resources that facilitate social mobilization, were integral to the battles for unemployment benefits, but that political rights, by themselves, are inadequate in shaping the development of social rights. Strong organization and political opportunities were also necessary to achieve a serious program of unemployment benefits. Finally, we consider the implications of our research for recent discussions of social citizenship.

To understand debates over social policy in regard to unemployment in the years between 1890 and 1950, we locate these debates in their concrete industrial and social context in nations that had relatively long democratic traditions. The period of our study roughly covers the period that David Landes entitled the era of the "Second Industrial Revolution" and Alfred Chandler, Jr. styled the "age of managerial capitalism".

\section{CITIZENSHIP, LABOR MARKETS AND UNEMPLOYMENT}

Unemployment policy, its language and the concept of unemployment, developed in the years between 1880 and 1910, as a result of the failure of markets to transform the existing labor force smoothly into the kind of workers demanded by the new industries of the Second Industrial Revolution. ${ }^{7}$ Once established, labor market institutions proved enduring, withstanding changes in demand caused by war or economic crisis.

'See ־hristian Topalov, Naissance du chộmeur, 1880-1910 (Paris, 1994). 
Throughout much of the period under discussion, English workers, who confronted high levels of unemployment, sought work in the British Commonwealth countries, mainly Canada, Australia and South Africa. In contrast, France and the United States faced long-term labor shortage and recruited workers from elsewhere. During the first three decades of this period, it was relatively easy for workers in all three countries to acquire citizenship in the nations to which they migrated, and the development of a national, broadly inclusive, welfare state made only slow progress anywhere. Meanwhile, the development of welfare states proceeded at fairly different rates in each of the three nations. But as we shall see, from its very origins, national unemployment policy in each country was strongly influenced by its relationship to foreign labor markets.

We begin by looking at unemployment policy in England, the home of the first Industrial Revolution; England found it harder to keep up in the race for industrial leadership during the Second Industrial Revolution because the existence of a substantial number of small-scale employers and a large labor force of both skilled and unskilled laborers encouraged employers to make the best of existing arrangements while only slowly introducing the new technologies. ${ }^{8}$ As a result, the growth of heavy industry in England remained behind such pioneers as the United States. English employers were hesitant to take on the responsibility for training semi-skilled workers who might, then, leave them for other employers. Instead, employers were inclined to substitute combinations of skilled and unskilled workers wherever they could. ${ }^{9}$ One consequence of such a policy was to make English employers concerned about efficiently finding the skilled workers that they needed while taking for granted the availability of unskilled laborers.

Unemployment, particularly of unskilled workers, was one important result of the uncertain shift towards the Second Industrial Revolution in England. The years after 1880 witnessed growing rounds of joblessness as the traditional staple industries, textiles, mining, and iron and steelmaking, failed to grow, while the unskilled workers that they released were unprepared for work in the newly developing industries. While local relief offered one alternative, many social thinkers emphasized emigration. Reinforcing their faith in the self-regulating market for wage laborers, most nineteenth-century English policy-makers believed that the operation of the international labor market would ensure that unem-

- On England's position in the Second Industrial Revolution, Andrew Gamble, Britain in Decline: Economic Policy, Political Strategy and the British State (London, 1981), pp. 8485 and E.J. Hobsbawm, Industry and Empire (Harmondsworth, 1972), p. 188.

- See Howard Gospel, Markets, Firms, and the Management of Labour in Modern Britain (Cambridge, 1992) and Joseph Melling, "Employers, Industrial Welfare, and the Struggle for Work-Place Control in British Industry, 1880-1920", in Howard F. Gospel and Craig R. Littler (eds), Managerial Strategies and Industrial Relations: An Historical and Comparative Study (London, 1983), pp. 55-81, especially p. 75. 
ployment would not be a permanent presence in English society, at least among able-bodied workers. ${ }^{10}$

The many emigration societies flourishing in the $1860 \mathrm{~s}$ and $1870 \mathrm{~s}$ testify to the seriousness attached to this alternative. ${ }^{11}$ Roughly 2.4 per cent of the native English population (net of returns) emigrated in the 1860 s and also in the 1870s and emigration rose sharply in the economically troubled 1880 s when 3.1 per cent of the population left and did not return. ${ }^{12}$ Disproportionately concentrated among the young adult population, emigration could have provided an outlet for as much as 4 or 5 per cent of the labor force in each decade. More important, however, for municipal welfare programs, was the changing composition of the emigrant population. For much of the first half of the nineteenth century, rural emigration, the departure of tenants and farm laborers from Ireland and Scotland as well as England, had dominated the migratory stream, but in the 1880 s urban migrants began swelling the tide. ${ }^{13}$ Cities such as Birmingham and London contributed a disproportionate share of this new migration, partly because, in bad times, urban charitable societies and even local government encouraged the emigration of unskilled workers. ${ }^{14}$

Many working-class English voters also saw emigration as a principal benefit of empire and a right of British citizenship. The Balfour government's decision in 1904 to authorize the use of indentured Chinese labor in the Rand mines in South Africa was one of the heated issues which contributed to the Conservative rout in $1906 .{ }^{15}$ According to Bernstein, "Liberal leaders argued that the Chinese would replace white labour in South Africa, limiting the opportunities for white migrants and hindering its development as a white man's country". ${ }^{16}$

Increasingly, however, in the early twentieth century, both industrialists and workers recognized the inadequacies of past approaches and devised new solutions. Some English businessmen doubted the value of

${ }^{10}$ In 1868, for instance, John Stuart Mill emphasized the importance of emigration as a solution for unemployment. The Collected Works of John Stuart Mill: Late Letters 18491873 (Toronto, 1972), p. 1454.

"For a discussion of various schemes, see Fred H. Hitchins, The Colonial Land and Emigration Commission (Philadelphia, 1931).

12 Dudley Baines, Migration in a Mature Economy: Emigration and Intermal Migration in England and Wales 1861-1900 (Cambridge, 1985), p. 88.

13 Ibid. Also see Charlotte Erickson, "Who Were the English and Scots Emigrants to the United States in the Late Nineteenth Century?", in Charlotte Erickson, Leaving England: Essays on British Emigration in the Nineteenth Century (Ithaca, 1994), pp. 87-125.

${ }^{14}$ William J. Fishman, East End 1888 (London, 1988), p. 56; Birmingham Daily Chronicle, 29 June 1912.

is A.K. Russell, Liberal Landslide: The General Election of 1906 (Hamden, CT, 1973), p. 196.

${ }^{16}$ George L. Bernstein, Liberalism and Liberal Politics in Edwardian England (Boston, 1986), p. 59. 
emigration as a solution for unemployment, because they believed that the market for skilled labor was functioning inefficiently. ${ }^{17}$ Among the leaders of the dissatisfied were Birmingham employers who lived in a city with a great variety of small metalworking industries that employed skilled men in many different but related metal trades. Birmingham business leaders lamented that, while skilled workers could use informal channels or trade unions to learn about vacancies within their own trade, they were often ignorant of vacancies in other trades demanding only slightly different skills. ${ }^{18}$ While skilled jobs in Birmingham went begging, employers from Philadelphia, Johnstown and Cleveland were recruiting skilled workers locally for American factories. ${ }^{19}$

In the years after 1906, workers' concerns about unemployment also increased. The continuing rise in unemployment, the sustained agitation around unemployment between 1905 and 1908, and the resolution of the nascent Labour Party to take up this issue all kept the question on the front burner. Learning from earlier movements against unemployment and organized in such bodies as the East London Unemployment Committee, the London Central Workers Committee, the Unemployed Citizens Association in Birmingham, working-class radicals had organized mass demonstrations that stoked popular discontent with the Conservatives. $^{20}$ As in the case of old age pensions, unemployment insurance came as a response to working-class demands for action. With the backing of the nascent Labour Party, trade unionists drafted a "Right to Work" bill which would have involved government funding to create work.

The result of these diverse pressures was the world's first compulsory unemployment insurance law. This Act was designed to take into account the demands of both big businessmen and trade unionists. For trade unionists, the Act provided governmental aid for their own section of the working class which was already highly organized into trade unions. For employers, the Act offered the compulsory registration of those skilled workers they were most anxious to move between trades. In its finished form, the unemployment provisions of the National Insurance Act of 1911 were devoted to regulating labor markets for skilled workers particularly susceptible to cyclic and seasonal fluctuation. While it marked an important advanice in the growth of an English welfare state, the working-class population it affected was much smaller than the voting

17 Joseph Chamberlain was unsympathetic to the emigration solution, and his alter-ego, Jess Collings, wrote a letter to the Birmingham Daily Post (12 February 1912) attacking poor law subsidies to emigration, which provoked considerable controversy.

is Ibid., p. 344.

19 Rowland Tappan Berthoff, British Immigrants in Industrial America (Cambridge, MA, 1953), pp. 70-71.

20 Richard Flanagan, "Parish-Fed Bastards": The History of the Politics of the Unemployed in Britain, 1884-1939 (Westport, CT, 1991), pp. 77-80. 
population. The bill made insurance compulsory in three trades: shipbuilding, engineering, and building and construction. These were also trades where unemployment "[. . .] was neither so frequent as to be uninsurable, nor so low as to be unnecessary". In July 1914, roughly two-thirds of the workers covered by the plan were skilled and almost all were male. ${ }^{21}$

Writing in 1975, T.H. Marshall asserted the radical nature of the National Insurance Act of 1911 as an example of the success of Liberal appeals to citizenship. Marshail claimed that "[...] it had more the character of an attack, not against industrialists personally, but against the capitalist economy of the nineteenth century and against the 'establishment' that tolerated its inhumanity". ${ }^{22}$ But those very theorists of social citizenship who so influenced Marshall recognized clearly that the 1911 Act was not an example of the triumph of the collective moral responsibility that they so desired. L.T. Hobhouse, perhaps the most prominent of the "New Liberals", critiqued the Act: "a man needs provision against sickness not because he is employed but because he is a man. The. state owes it to him not because he is employed but because he is a citizen". ${ }^{23} \mathrm{He}$ criticized the act because it hit the poorest too hard, because it was not a charge on the "surplus" and so redistributional, and because it was a tax on production that would finally be reflected in prices. ${ }^{24}$

In the inter-war years the issue of unemployment again came to the fore. The persistent, grinding unemployment which reappeared in many important industrial regions after the initial spurt of prosperity that followed the Armistice, continuing until the British economy began preparing for World War II, made unemployment policy a central issue. ${ }^{25}$ Beginning in 1900 and accelerating in the inter-war period, many British politicians advocated a government employment policy and unemployment insurance, but others emphasized a reorganized and revitalized empire and imperial emigration as solutions to British unemployment. ${ }^{26}$ While the Conservative governments of the inter-war years put emphasis on imperial solutions, practical politicians were forced to concede that, as the agricultural crises of the 1920s broadened into the Great Depres-

21 Pat Thane, The Foundations of the Welfare State (London, 1982), p. 95.

2 T.H. Marshall, "The Coming of Social Insurance", in Marshall, Social Policy in the Twentieth Century (London, 1975), ch. 4, p. 54.

${ }^{23}$ Stefan Collini, Liberalism and Sociology: L.T. Hobhouse and Political Argument in England, 1880s-1914 (Cambridge, 1979), p. 111.

24 Ibid.

25 The most able discussion of inter-war unemployment in Britain is W.R. Garside, British Unemployment, 1919-1939: A Study in Public Policy (Cambridge, 1990).

${ }^{26}$ Stephen Constantine, "Introduction: Empire Migration and Imperial Harmony", and Keith Williams, “A Way Out of Our Troubles: The Politics of Empire Settlement, 19001922", in Stephen Constantine (ed.), Emigrants and Empire: British Settlement in the Dominions between the Wars (Manchester, 1990), pp. 1-45. 
sion, the colonies were far less willing than before the war to receive British emigrants. Part of the problem was the implementation of US migration restrictions which led many Eastern European migrants to direct themselves towards Canada. Below the surface, however, were even more formidable obstacles. Increasingly, the Dominions hesitated in favoring British migrants for they found the new urban migrants to be "single, young, footloose, unskilled and had a high likelihood of returning home". ${ }^{27}$ In 1924, to promote migration as a solution to urban unemployment and, also, to better aid the "redistribution of the white population of the Empire", an Empire Settlement Act was passed. But British efforts to open the Dominions to emigration proved illusory. A 1932 committee on migration concluded that "[...] we are now confronted by a profound disharmony between the economic needs of Great Britain on the one hand and the Dominions on the other in regard to migration. Now that it might suit us to send large numbers of our people to the Dominions, it does not suit the Dominions to receive them $[\ldots]$ ". ${ }^{28}$

Declining opportunities for emigration coinciding with unprecedented unemployment put great pressure on an English relief system already reeling from the problems of the post-World War I period. The difficulties of demobilization, accelerated by the post-war upsurge of labor militancy, had forced British politicians to open the unemployment system to soldiers and to unemployed war workers and their families. But as workers' militancy was repressed or declined and long-term unemployment remained, Conservatives restructured unemployment insurance by restoring its actuarial soundness and consigning many of the unemployed to a "dole", designed to humiliate workers and drive them to the wage market.

Together, the changing demands of some large employers and many trade unionists combined with the loss of the "right" of imperial migration and the increased reliance on the traditional disciplinary spirit of English poor relief, created a popular demand for a new approach to the problem of unemployment. ${ }^{29}$ Yet, as we shall see in our discussion of political opportunities, it took political breakdown, the collapse of

27 Baines, Migration in a Mature Economy. Already by 1908 the Canadian government was having second thoughts about admitting migrants from "[...] the vastly populated and greatly congested East End of London [. . .]" because "the conditions under which they had lived, and in which in all probability their parents for several generations have lived, do not produce the kind of men who are fit for labour which Canadian farmers have to offer [. . . ]": report by Bruce Walker to the Interior Department of the Government of Canada, 10 January 1908, cited in Report of the Immigration Commission, The Immigration Situation in Other Countries: Canada, Australia, New Zealand, Argentina, Brazil (Washington, 1911), p. 113.

28 Birmingham Post, 13 May 1932.

29 See Scott Newton and Dilwyn Porter, Modernization Frustrated: The Politics of Industrial Decline in Britain since 1900 (London, 1988). 
the existing British order in the wake of appeasement and war, to turn popular revulsion into a new politics.

In terms of the relationships between labor supply, migration, and the labor movement and citizenship, the French experience provides a dramatic contrast to that of the British. Labor shortage was the characteristic feature of French heavy industry; fertility decline combined with the prevalence of smallholding had made it difficult for employers to recruit semi-skilled workers. Nonetheless, the character of technological change in the 1890s enabled France to adapt better than the UK to the needs of industrial transformation. Although French industrialists emulated their British rivals and sought to conserve their old plants as long as possible, in some crucial industries such as steelmaking and chemicals, they found the continuation of traditional methods less practical. The introduction of a new steelmaking process, the ThomasGilchrist method, which valorized the hitherto unusable ore of the Briey basin, and an ensuing wave of inventions forced an overhaul of the entire French metalworking industry. Metalmaking moved in the direction of the Lorraine ore fields while old centers of metalworking had to turn to new types of machine-making. The result was to force the introduction in France of the new technologies of the Second Industrial Revolution. ${ }^{30}$

Innovating large industrialists soon confronted the persistent and enduring French problem of labor shortage. According to Gerrard Noiriel, "Between 1900 and 1930, French heavy industry was handicapped by a lack of workers (semi-skilled workers [spécialistes] chiefly) which constrained employers to make considerable efforts in recruitment and personnel training." 31 For much of the pre-war period, industry turned to temporary migrants from French agriculture and to the recruitment of women workers. But the requirements of industry and then the toll of war led France to turn seriously toward foreign emigration during World War I and its aftermath. For example, between 1911 and its inter-war high point in 1926, the foreign-born residents of the Arrondissement of Saint-Etienne, the county-sized district that included SaintEtienne, increased by roughly seven and a half times; in the same period, the foreign-born population of Paris and its banlieue increased by almost 50 per cent, from 7 to 10 per cent. ${ }^{32}$ Increasingly, migration

\footnotetext{
${ }^{30}$ On French industrial development see Charles E. Freedeman, The Triumph of Corporate Capitalism in France, 1867-1914 (Rochester, 1993) and M.J. Rust, "Business and Politics in the Third Republic: The Comite des Forges and the French Steel Industry, 1896-1914" (Ph.D., Princeton University, 1973).

${ }^{31}$ Gérard Noiriel, "Du 'patronage' au 'paternalisme': la restructuration des formes de domination de la main-d'oeuvre dans l'industrie métallurgique française", Le Mouvement social, 144 (July-September 1988), pp. 17-35, especially p. 28.

${ }^{32}$ The census of 1911 listed 1,683 foreign-born in the Arrondissement of Saint-Etienne. Wartime losses and post-war prosperity only exacerbated Stéphanois labor requirements.
} 
became a matter negotiated between the French government and foreign governments rather than a free market phenomenon. ${ }^{33}$ Intergovernmental migration agreements usually required guarantees that migrant workers would receive the same social welfare benefits as their French counterparts; other migrant workers lacked such rights. French desperation about population decline, intensified by the casualties of the war, led the government to make such concessions; it even led the French government to obtain children secretly from foreign orphanages and entrust them to industrialists to employ in their factories. ${ }^{34}$

The dominant assumption of the 1920s, that labor scarcity was a foremost problem, helps explain the lack of public interest in the unemployed and the cursory system of unemployment relief in France. The government -mandated departments and localities to take care of the unemployed, and helped subsidize the cost of local authorities as well as those few trade unions and trade organizations that provided unemployment benefits. The law provided leeway for local initiative but it mainly permitted local neglect. When France began to overhaul its social welfare laws in the early 1920s, an employer participating in a government sub-committee to rewrite the law, argued that unemployment should not be included. He noted that "[. . .] people have said that 'the French suffer least from unemployment' but in reality it is because France is less peopled [...] unemployment insurance is less necessary, less urgent in France than elsewhere". ${ }^{35}$ Left undiscussed was the plight of that 6 per cent of the French population who were immigrants and particularly vulnerable to unemployment. By 1931, this percentage had risen to almost 7 per cent; 40 per cent of all coalminers, 35 per cent of all metalworkers, 26 per cent of all quarryworkers and 24 per cent of all construction workers were emigrants. ${ }^{36}$

One of the most important political consequences of this long-term labor shortage and the consequent reliance of French industry on migrant labor was that, in times of economic downturn, citizenship membership could be invoked as a way of dealing with unemployment. Thus, in France, citizenship served as an alternative to dealing with the larger problem of structural change and the extension of social rights. The Great Depression of the 1930s shows how appeals to citizenship could

By 1921, the number of foreign-born migrants had increased five-fold to 7,626 , to reach a maximum of 12,618 in 1926.

33 See Gary Cross, Immigrant Workers in Industrial France: The Making of a New Laboring Class (Philadelphia, 1983).

${ }^{3}$ See, Le President du Conseil, Ministre des affaires étrangers à Monsieur le Prefet de la Loire, 8 février, 1924, Archives départementales de la Loire (ADL), Msup520.

${ }^{35}$ M. Louis Lemarchand (Patron - filateur et tisseur de coton, Rouen, Normandy), p. 169. Ministère du Travail, Vingt-Sixième session, Novembre 1922 (Paris, 1923).

${ }^{36}$ Cross, Immigrant Workers, p. 160. 
bring together the nationalist right and elements of the republican socialist left.

As long as it was a question of single workers, French industrialists were usually willing to go along with nativist appeals. Essentially, the employers' and the local municipality's attitude towards immigrants in the post-World War I period was similar to their attitude towards French seasonal migrants before the war. In bad times, seasonal or temporary workers were let go, and migrant workers belonged disproportionately to this latter category. French employers continued to pursue this strategy in the 1930s despite the unusual length of the economic downturn; while never reaching the levels of the United States or Germany, it nonetheless remained remarkably persistent, almost up to the very outbreak of World War II. But even when faced with labor surpluses, employers were unwilling to fire married male workers with families on the assumption that sooner or later labor scarcity would return, and they did not want to lose the most stable elements of the workforce. ${ }^{37}$ Increasingly, also, the French government began to discriminate against married female public. workers, discharging them in favor of males who were supposed to be heads of households.

While French employers sought to retain adult male workers no matter what their nationality, the right-center coalitions that governed France in the early 1930s sought to cure unemployment by returning immigrants to their homes. In 1934, in a report from the département of the Loire, the Prefect noted that "industrialists prefer to employ French workers with families". Although employers were not necessarily as enthusiastic about his policy as he implied, the Prefect had aided 1,400 foreign workers and their families to return to their countries of origin. ${ }^{38}$ Because employers wished to hold on to skilled workers or because they felt that French workers would not perform the hardest forms of cheap labor, foreign workers generally proved more difficult to repatriate than French authorities usually assumed. Nevertheless, an extensive study of French unemployment estimated that somewhere around 180,000 migrants left France between 1931 and 1935 with 60,000 of them leaving the Paris region alone. ${ }^{39}$

As the Depression continued, the pressure on immigrants intensified. In 1932, conservative legislators introduced and secured the passage of

37 A distinguishing feature of French unemployment in the inter-war period was its concentration among younger and older workers as French employers did everything that they could to retain adult males with families against the possibility of future labor shortages. In contrast to England and the United States, French employers discharged disproportionately large numbers of the elderly while seldom substituting younger (and more mobile) workers for mature adults. See Gabrille Letelier, Jean Perret, H.E. Zuber and A. Dauphin-Meunier, Le Chómage en France de 1930 à 1931, tome 1 (Paris, 1938), pp. 71-79.

${ }^{38}$ ADL Msup550.

${ }^{39}$ Lętelier et al., Le Chómage en France de 1930 a 1931, tome 1, pp. 130 and 137. 
a "Law for the Protection of National Labor". This law gave the government the power to impose quotas on the hiring of immigrants in many industries, but the law met with considerable resistance on the part of employers and, initially, had little impact on the national labor market. Nonetheless, individual administrators took the law as a signal to launch their own campaign. The Labor Ministry constituted a fund to pay the return of emigrants and, in key regions, such as the departement of the Seine, the Prefect simply turned down a high proportion of all applications for the identity cards which were obligatory for all workers. In 1934 the Flandin government began applying the quotas more vigorously. Except in the case of political refugees, the Popular Front brought little relief for emigrant workers. The Blum government pursued, although less tenaciously, the anti-immigrant policies of its predecessors, and the end of Léon Blum's second cabinet witnessed the most repressive immigrant policies of the whole period..$^{40}$ In 1938 , prolonged unemployment reduced industrialists' concern to secure access to migrant labor, and a resurgent right actually began to apply rigorously the law on quotas. ${ }^{41}$

The right-wing campaign against migrants was facilitated because their initiatives met with little resistance, and sometimes active support, on the left. As unemployment deepened in the mid-1930s, confrontations between unemployed French workers and migrants became more common. ${ }^{42}$ The major French trade union, the Confédération générale du travail (CGT) and the Socialist Party (SFIO), who both opposed forced repatriation, insisted increasingly on the better regulation of foreign labor which meant a closing off of foreign migration, and they began to favor quotas on new hirings.

Even the Communist commitment to the migrants' cause, based on proletarian internationalism, wavered. The victory of the Popular Front, remembered by so many as a left-wing triumph, appeared differently to immigrants who felt that campaigns against foreign workers were legitimized by Léon Blum's depiction of the Popular Front as a government of "republican defense". ${ }^{43}$ The emphasis on the centrality of the national

\footnotetext{
${ }^{40}$ See Catherine Wihtol de Wenden, Les immigrés et la politique: Cent cinquante ans d'evolution (Paris, 1988), ch. 2. Marcel Livian has attempted to rebut the accusations of Jean-Charles Bonnet and others that the Blum government was unreceptive to the needs of migrants, but his response is entirely unpersuasive except in so far as he points out the Blum government's concern with political refugees. See Livian, Le Parti socialiste et l'immigration: Le gouvernement Léon Blum, la main-d'oeuvre immigrée et les refugies politiques (1920s-1940) (Paris, 1982).

${ }^{4}$ See Jean-Charles Bonnet, Les pouvoirs publics français et l'immigration dans l'entre deux guerres (Lyon, 1976), pp. 272-280.

12 Ralph Schor, L'Opinion française et les étrangers en France 1919-1939 (Paris, 1985), pp. 561-565.

${ }^{43}$ See chapter V, "'Liberty' defending democracy", in Julian Jackson, The Popular Front in France Defending Democracy, 1834-38 (Cambridge, 1988), pp. 149-158.
} 
community relegated non-nationals to a secondary status. Ralph Schor's study of French xenophobia demonstrates that when the Communists turned to the Popular Front "they abandoned their old principles, and in order to appear more reassuring, they ceased systematically supporting foreigners". ${ }^{44}$ In the Longwy steel basin, Italian immigrants, many of whom were Communists fleeing Mussolini, were disturbed to see the red flag yielding to the tricolor in rallies and to find themselves urged to "die for France". In 1937 the local Communist Party held a rally around the theme of "France for the French". ${ }^{45}$

Because unemployment was less salient in France and its burden was placed disproportionately on the backs of the young, the old and the foreign, not on those adults who composed the main part of the ranks of organized labor, it is not surprising that unemployment was a low priority among French workers in the reformist period immediately following World War II. Although all the major parties that emerged in the immediate post-World War II period had programs that favored the adoption of some form of national unemployment insurance, it was not a high priority for any party. ${ }^{46}$ French political rhetoric continued to downplay the importance of unemployment. According to Pierre Laroque, the major architect of the post-war welfare system: "It may seem strange that the French organization of social security as set up in 1945, gave no place to unemployment, whereas the British plan of the same period was completely centered on coverage for unemployment [...]. The reason is that unemployment at that time did not really worry either the public or the authorities. ${ }^{47}$ The claim that "the public or the authorities" were not worried by unemployment is false, but the grim truth is that much of the burden of unemployment in France during the inter-war years had been shouldered by groups who did not, then, constitute the "public" and who did not seriously threaten the "authorities".

Thus, the struggle for unemployment insurance in France was crippled because workers invoked political rights as a substitute for social rights and because the French right tried to turn foreign workers into a kind of reserve army of the proletariat. Although the immigrant option remained important to French employers and was never fully eradicated, in time of high unemployment citizenship rights advantaged native industrial workers. Even when the fall of the Vichy regime finally secured French workers full possession of civil and political citizenship and led

4 Schor, L'Opinion française, p. 596.

4s Gérard Noiriel, Longwy immigrés et prolétaires 1880s-1980 (Paris, 1984), pp. 306-309.

${ }^{46}$ Andrew Shennan, Rethinking France: Plans for Renewal 1940-1946 (Oxford, 1989), pp. 221-223.

${ }^{77}$ Pierre Laroque, "Chapter Seven: Social Security in France", in Shirley Jackson (ed.), Social Security in International Perspective (New York, 1969), pp. 171-189. On' the post-war programs of French political parties, see Shennan, Rethinking France. 
to the conquest of new social rights, these very rights made them, their employers and the government reticent to expand social citizenship to deal with problems of unemployment because unemployment necessarily involved dealing with the issue of migrant workers.

If English employers assumed a surplus labor pool and French employers an enduring shortage of semi-skilled workers, American employers faced a labor market in which they could not depend on an abundance of skilled workers; the American solution was to rely on rapid mechanization of their industries, international migration and, to some extent, black migrants from the South. A look at New York and Pittsburgh provides insight into how the immigrant nature of the workforce shaped the expansion of American industry.

In 1910, 40.4 per cent of the New York population was born outside the US compared with 4.5 per cent of the population of London and 7.3 per cent of the Parisian population (banlieue included) in $1911 . .^{48}$ Between 1890 and 1914 , large numbers of newly arrived immigrants from Eastern and Southern Europe transformed the garment and fashionrelated industries which dominated New York's industrial sector. Jewish and Italian immigrant women and children provided a ready pool of cheap labor for the garment industry. The new era of expansion in garments was characterized by an increasing subdivision *of labor, as New York employers sought to maximize the use of labor which, in contrast to European garment workers, was not very skilled.

Heavily mechanized by the turn of the century, Pittsburgh industry also dealt with the lack of a skilled labor force, in particular, and a potential labor shortage, in general, by turning to new sources of labor. The electrical industry, especially canning, relied heavily on women workers who did arduous work at low wages. ${ }^{49}$ In steel, Pittsburgh's primary industry, employers who in the nineteenth century depended on immigrants from England and Ireland to supplement the native-born

\footnotetext{
48 Despite the dramatic decrease in intercontinental migration caused by World War I and the American immigration laws of the 1920s, England and France had very different experiences from those of New York: in 1930, 33.1 per cent of the New York population was born outside the United States. The inter-war crisis led to a wave of increased immigration to France; in 1931, 12.1 per cent of the Parisian population was born outside France, but it had no impact on England, where 5.2 per cent of the population was born outside the United Kingdom, with 1.2 per cent of this foreign-born population coming from the Irish Free State. The numbers of children aged 10-14 available to do sweated -labor remained high in New York City, despite World War I and the imposition of migration restrictions in the 1920s. The percentage of children aged 10-14 of the foreignborn parents among the total second generation population in the $1920 \mathrm{~s}$ was 14.5 per cent, in 1930 it was 14.1 per cent. All information comes from national censuses for the three nations.

49 See Elizabeth Beardsley Butler, Women and the Trades, The Pittsburgh Survey 1 (New York, 1909). See also Ronald Schatz, The Electrical Workers of General Electric and Westinghouse, 1923-1960 (Urbana, 1983), ch. 2.
} 
whites, encouraged the employment of Eastern Europeans and in some measure African-Americans. In the 1880 s, the workforce was just over one-third foreign born, but by 1910 it was one-half, with the largest jump occurring after 1900. Rapid mechanization in heavy. industry enabled employers to maximize their use of new immigrant labor. In the early years, Slavic and Italian laborers often moved back and forth from Europe to the United States, but settled immigrants took on the ever increasing number of unskilled jobs, working in blast furnaces, foundries or doing common yard labor. ${ }^{\text {so }}$

In heavy industries such as steel, American employers confronted less union resistance than their European counterparts. While there were important upsurges in union activity in the late nineteenth century, unionization had been seriously weakened after the 1890s, as evidenced by important strike defeats, in 1892, 1902 and $1919 .{ }^{51}$ Steel employers could roll back unionization precisely because they relied so heavily on newcomers who could be easily trained, outside union apprenticeship programs, for less skilled jobs. And the garment industries in New York and elsewhere staved off serious union victories until the second decade of the century.

The continuing influx of immigrants between the late nineteenth century and World War I kept wages low and undercut the strength of unions so that during economic downturns, the crises of unemployment were quite massive, visible and potentially explosive. During economic downturns in Pittsburgh unskilled workers returned home, thus reducing the unemployment crisis. Nevertheless, the downturns themselves were deepened by the large numbers of immigrants who arrived in the city during the preceding good times. ${ }^{52}$

In times of crisis, massive immigration affected-the responses of local communities, trade unionists and business leaders. With local relief funds in short supply, immigrants, usually dismissed from jobs first, were often denied work relief because of their alien status. In Pittsburgh, the policy was supported by skilled unions affiliated with the American Federation

${ }^{50}$ See US Senate, Report on Condition of Employment in the Iron and Steel Industry III, US Senate Document 110, 62d Congress, first session, Appendix C: "Characteristics of the Labor Force in a Representative Steel Plant in the Pittsburgh District" (Washington, 1913), pp. 479-480. In this report, the Pittsburgh district refers to an industrial area beyond Allegheny County; it included the steel producing communities around Youngstown, Ohio, and in West Virginia.

s1 On the history of unionizing by the Amalgamated Steel and Iron Workers, see among others, John Fitch, The Steel Workers, The Pittsburgh Survey 2 (New York, 1911); David Brody, Steelworkers in America, the Non:union Era; Brody, Labor in Crisis.

52 Peter R. Shergold, Working Class Life: The "American Standard" In Comparative Perspective, 1899-1913 (Pittsburgh, 1982), pp. 40, 41; see also J.T. Holdsworth, "Report of the Economic Survey of Pittsburgh", 1911 (Archives of Industrial Society, University of Pittsburgh), p. 142; Paul Kellogg (ed.), Wage-Earning Pittsburgh, The Pittsburgh Survey . (New York, 1914), p. 37. 
of Labor. ${ }^{53}$ Since the latter decades of the nineteenth century, the AFL had been obsessed with the problem of unemployment and underemployment; when their campaigning for a shorter workday failed as a means of maintaining low levels of unemployment, they turned to a greater effort at restricting the labor market, such as efforts to limit female employment and prohibit child labor. By the end of the nineteenth century, increasingly, the AFL framed the problem of unemployment as one of unrestricted immigration. ${ }^{54}$ As Gwendolyn Mink has well shown, through its alliance with the Democratic Party, the AFL directed almost all of its attention towards influencing national politics on two issues - one was the effort to end legal constraints on union activities, and the other was immigration restriction. ${ }^{55}$

While a number of middle-class reformers and some American radicals were calling for greater state regulation of unemployment, the AFL contended that the rights of American working (men) would have to be guaranteed by unions alone - indeed, the AFL was suspicious of any outside efforts to provide benefits that might undercut their own functions. ${ }^{56}$ Total dependence on union strength, however, in this new context of a soft labor market, increased the stakes in the campaign for immigration restriction. Thus, the concept of right to work, and, indeed, even to work relief, for the AFL can be seen as an appeal for the rights of (white, male) citizenship, defined in an exclusionary way, with increasingly nativist overtones. ${ }^{57}$

For American social reformers concerned about unemployment, the immigration question was problematic. The early 1900s saw commission, after conference on the relationship between immigration and unemployment. In 1902, when Congress took up the issue of immigration restric-

53 Shergold, Working-Class Life, p. 40.

st Alex Keyssar, Out to Work: The First Century of Unemployment in Massachusetts (Cambridge, 1986).

ss Gwendolyn Mink, Old Labor and New Immigrants in American Political Development: Union, Party and State, 1875-1920 (Ithaca, NY, 1986). At the end of the nineteenth, and during the early twentieth, century the National Labor Tribune, the Pittsburgh labor weekly put out by AFL unions, ran a limited number of stories on national news which they believed were relevant for their readers - the fate of legislation on industrial protectionism, efforts to elevate standards of children's education, mothers' pensions, protective hours legislation for women and immigration restriction.

so On steel, see Brody, Labor in Crisis; Daniel Nelson, Unemployment Insurance, p. 47. See also Fitch, The Steel Workers, The Pittsburgh Survey 2, Appendix II, for rules and - regulations of the Amalgamated Association of Iron and Steel Workers with respect to benefits, especially pp. 270-277. On the unions' suspicion of the employers' motives for offering benefits, see chapters XV and XVI.

57 See Nick Salvatore, "Some Thoughts on Class and Citizenship in the Late Nineteenth Century", in Marianne Debouzy (ed.), In the Shadow of the Statue of Liberty: Immigrants, Workers and Citizens in the American Republic, 1880-1920 (Urbana, 1992), pp. 211-228 and Catherine Collamp, "Union, Civics and National Identity: Organized Labor's Reaction to Immigration, 1881-1897", in In the Shadow of the Statue, pp. 229-255. 
tion, Edward Devine of the Charity Organization Society weighed in with the AFL, noting that immigrants replaced American labor, diluted American citizenship and created every year "a more and more serious menace"..$^{8}$ The concern over immigration's effect on labor intensified after the panic of $1907 . .^{59}$ Among many reformers, a policy of immigration restriction conflicted with their inclusive ideology; for others such as labor economist and reformer William Leiserson, their own immigrant background made such a policy distasteful. Thus they turned to private schemes for redistributing immigrants away from the cities. ${ }^{60}$ Increasingly, social reformers called for state regulation in the form of employment bureaux as a means for redistributing immigrants. In calling for the establishment of a state bureau of immigration, J.T. Holdsworth noted that "No city has a more vital interest in the regulation distribution and assimilation of the immigrant than Pittsburgh [...] Thousands of immigrants who under the present lack of supervision go into mines, mills and factories should be directed to agricultural and other pursuits". ${ }^{61}$ Each economic crisis, and the social protests that often accompanied them, brought renewed efforts from such reform organizations as the American Association for Labor Legislation (AALL) on behalf of greater state intervention in the form of the establishment of public employment bureaux, work relief and for some form of unemployment insurance. ${ }^{62}$ Activists were influenced by the efforts surrounding social insurance in England. ${ }^{63}$ But unlike the British plan, many called for unemployment insurance schemes that would require industries to set up individual reserves in the hope that if undertaken by each individual corporation, they would serve as an incentive to prevent unemployment through careful, regularized employment practices. ${ }^{64}$

American industrialists, however, remained committed to their traditional right - to regulate labor without state imposition. By the 1910s, a number of American corporate leaders, such as Marion Folsom and

${ }^{58}$ Paul T. Ringenbach, Tramps and Reformers, 1876-1916: The Discovery of Unemployment in New York, (Westport, CT, 1973), p. 143. Devine quoted and paraphrased.

59 See lbid. This partly explains the tone surrounding the discussion of new immigrants in the famous US Immigration Commission reports made to the Congress in 1910.

${ }^{60}$ William Leiserson, Adjusting Immigrant and Industry (New York, 1924). See Ringenbach, Tramps and Reformers, ch. 4, on the efforts of the Hebrew Emigrant Aid Society to relocate Russian Jews on farm land in New Jersey.

61 See "Report of the Economic Survey of Pittsburgh", 1911, pp. 142, 143.

62 Isaac Rubinow, Social Insurance (New York, 1913) and Henry Seager, Social Insurance: A Program of Social Reform (New York, 1910). See also Ringenbach, Tramps and Reformers; Roy Lubove, The Struggle for Social Security, 1900-1935 (Cambridge, 1968), ch. VII; Daniel Nelson, Unemployment Insurance: The American Experience 1915-1935 (Madison, WI, 1969).

${ }^{63}$ See Ibid. See also Theda Skocpol, Protecting Soldiers and Mothers: The Political Origins of Social Policy in the United States (Cambridge, MA, 1992), ch. 3.

of Ibid. 
Gerald Swope, were engaged in voluntary efforts to regularize employment. At the forefront of the "New Emphasis" movement among American businessmen, which reached a zenith in the early 1920s, they embraced corporate unemployment insurance as part of the growing interest in scientific management, a means of regularizing labor and staving off possible state intervention. ${ }^{65}$ In most cases, the concern for stabilizing employment through a limited form of unemployment benefits, profit sharing schemes, or old age pensions, did not extend to their unskilled, immigrant labor force. ${ }^{66}$ Daniel Nelson has estimated that about twenty-three American companies had some form of unemployment schemes between 1916 and 1931, but only sixteen of them at any one time. ${ }^{67}$

Among the most significant examples of unemployment insurance in corporate America was put into place by the Amalgamated Clothing Workers of America (ACWA) in the post-World War I years. In the pre-war years, 'needles' trades unions, like the others in the AFL, advocated shorter hours and restricted production as a way of dealing with unemployment. But, unlike traditional AFL unions, the immigrant dominated garment unions could not attack the problem of unemployment by invoking the rights of American citizens; they could not advocate immigration restriction or try to restrict the entrance of immigrants into the trade. ${ }^{68}$ After the war, despite the end of open immigration, rapid mechanization continued to exacerbate unemployment in this seasonal industry. By the early 1920s, ACWA leader Hillman, in alliance with such unemployment insurance advocates as John R. Commons and William Leiserson, appealed to clothing manufacturers for a program of unemployment insurance which would help regularize the conditions of work and production in this highly competitive industry. In 1922, an unemployment insurance plan, providing for joint employer/employee contributions took hold, covering 30,000 workers in 350 companies. ${ }^{69}$

Increasingly by the 1920 s, unionists such as Hillman, along with some reformers, began advocating state guarantees of corporate cooperation. Paul Douglas of the University of Chicago, for example, who had once hoped to see corporate unemployment benefits work as an incentive to

\footnotetext{
os See Nelson, Unemployment Insurance, ch. 2; see also Sanford M. Jacoby, Employing Bureaucracy: Managers, Unions and the Transformation of Welfare in American Industry (New York, 1985); Jacoby, "Employers and the Welfare State: The Role of Marion B. Folsom", Journal of American History, 80:2 (September 1993), pp. 525-556; Ronald Schatz, The Electrical Workers (Urbana, 1983); Gerald G. Eggert, Steelmasters and Labor Reform: 1886-1923 (Pittsburgh, 1981); Alan Dawley, Struggles for Justice: Social Responsibility and the Liberal State (Cambridge, MA, 1991).

66 On steel see Brody, Labor in Crisis.

${ }^{67}$ Nelson, Unemployment Insurance, p. 47.

${ }^{68}$ Ibid., p. 81.

69 Steven Fraser, Labor Will Rule, Sidney Hillman and the Rise of American Labor (New York, 1991), p. 217.
} 
minimize layoffs, now became convinced unemployment was a structural problem and was one of a number of activist intellectuals turning to the state as the guarantor of unemployment relief. ${ }^{70}$ But even as activists were increasingly calling for some expansion in the rights to unemployment benefits, the business community was able to hold out against such state mandated guarantees, so long as economic crises were short term; that was true - until 1929.

\section{CITIZENSHIP, POLITICAL OPPORTUNITIES AND LABOR MARKETS}

A look at the relationship between the labor markets of the Second Industrial Revolution and unemployment policy can explain a great deal about the evolution of national unemployment policy, but is, in itself, seriously incomplete. Everywhere, even when old labor market institutions had broken down, the shaping of new ones required government intervention. To break with the old political and economic order and to build a new welfare state demanded a breakdown in the cohesion of the established order and not simply the mobilization of new soccial groups. In all three countries, middle-class reformers and government policy-makers played a strategic role in making use of political opportunities and forging support for reform among various groups of industrialists and trade unionists.

The analysis that follows suggests that Marshall grossly simplified the relationship between universal citizenship and universal entitlement. We want to stress two chief differences. First, while Marshall believed that the welfare state eventuated from a shared sense of national unity, we emphasize that the major stages in the growth of modern welfare states resulted from explosive divisions within existing ruling coalitions. Such divisions opened the way for new approaches and presented new opportunities for politically excluded groups. Not a gradual expansion of consensus but a dramatic increase in political dissension built welfare states. $^{71}$

Secondly, Marshall viewed both political rights and social rights as expanding smoothly until they embraced everyone. It is true enough that Marshall concentrated his attention on Britain and never claimed that his argument applied generally to industrial countries. But our findings imply that a more comparative perspective might have enabled Marshall to identify the unique characteristics of the British situation

\footnotetext{
70 See Nelson, Unemployment Insurance.

"On "mobilization", see Charles Tilly, From Mobilization to Revolution (Reading, MA, 1978). The idea of a "political opportunity structure" draws on the work of Doug McAdam, Political Process and the Development of Black Insurgency, 1930-1970 (Chicago, 1982). See also the idea of "critical junctures" developed by Ruth Berins Collier and David Collier, Shaping the Political Arena (Princeton, 1991).
} 
that explain the salience of citizenship, thus necessitating the reshaping of his argument. In the UK, gradual suffrage expansion was the case during the years between 1832 and 1950; but in France the battle against democratic political rights and over the existence of the republic itself raged with great heat at various periods during the years between the 1870s and 1945. As we shall see, in their efforts to preserve political rights, French male workers were usually forced to sacrifice their demands for social rights. And if political rights, once obtained, were never permanently reversed in any of the three nations, the obstacles facing foreign migrants in becoming citizens increased substantially in each of the three nations. While citizen rights advanced, migrant rights to citizenship contracted. And in those nations, like France and the United States, with a substantial migrant population, unemployment policy was influenced by the degree to which migrants possessed citizenship.

In order to ëxamine how workers' and employers' perspectives on unemployment were translated into legislation, we begin by exploring the origins of the two chief periods of opportunity for social reform in England, the period between 1906 and 1911 and that between 1940 and 1945; and we will conclude by examining the role of middle-class reformers during these periods of political opportunity. In the years between the 1890s and 1950, there were two occasions when the force of political events so shattered the existing party system that substantial new political opportunities were created for the labor movement. The first occasion, cresting in 1906-1911, had its roots in the suffrage expansion of 1884, Joseph Chamberlain's secession from the Liberal Party in 1886 , and his adherence to protectionism in 1903. Without the realignment that occurred in British politics between 1886 and 1903, there would have been little chance for Birmingham employers' interest in labor exchanges and compulsory unemployment registration to have significantly affected debates over social reform; doubtless many employers' attitudes would have remained inchoate or only half articulated. And suffrage extension forced political parties to compete for the allegiance of new sections of the electorate, many of them industrial workers.

The entry of a new group of workers on to the electoral scene presented opportunities tempting for both parties. While most trade union leaders were Liberals, many working-class constituencies were more sympathetic to the Conservatives. Some workers suspected that the Liberals' attention to Irish autonomy was a pretext for avoiding social issues. ${ }^{2}$ In the 1890 s Conservatives wooed workers with the promise of social reforms. In 1903, Joseph Chamberlain's public advocacy of protectionism split the British elite down the middle, with many, but

7 D.A. Hamer, John Morley: Liberal Intellectual in Politics (Oxford, 1968), pp. 255-266. 
not all, large industrialists coming down on the side of protectionism. Chamberlain tried to use protectionism to appeal to workers, noting that "[... . alien legislation, sweating legislation, fair wages legislation is absolutely contrary to Free trade [...]". ${ }^{73}$

Some Liberals were not afraid to meet Chamberlain's challenge, but the mainstream of Liberals lamented, in Hubert Gladstone's words, that "[. . . ] Conservatives had lost all their principles and had disappeared: it had become a race between two parties, one outbidding the other". ${ }^{74}$ Despite the Conservative effort, it was the Liberals who won the battle for the working-class vote by better responding to workers' needs. The great Liberal victory of 1906 provided the setting for the passage of the first unemployment insurance act in 1911.

The triumph of almost universal suffrage in 1918 and 1919 provided the basis for radical advance in the post-World War I period, but the second great occasion for the remolding of the party system did not occur until the outbreak of World War II. Suffrage expansion was important because the enfranchisement of the mass of unskilled workers fueled the growth of Labour and enabled it to replace the Liberals. It took time for Labour to mobilize this new constituency but, already by 1934, Labour had won control of the London County Council, a majority lost to the left since the $1890 \mathrm{~s}$, and it did so on the basis of the newly-enfranchised workers.

If the suffrage extension made Labour the dominant party of the left, it took a serious political conflict, the crisis of wartime leadership, to provide the opportunity for a major transformation of the political order. Not war but the specific politics of World War II gave organized workers a vastly strengthened place within the political system and built the modern British welfare state. While large-scale warfare provided the chance for social reform by breaking up old ruling coalitions and eliciting promises for benefits to those who contributed unstintingly to the war effort, it did not, by itself, entail social reforms. Promises were given too liberally for all to be kept, and if established coalitions were restructured, victorious new coalitions might also be less sympathetic to reform. To understand the impact of war on social reform, attention must be paid to the politics of particular wars and the dynamics of wartime mobilization. One of the most important reasons for the triumph of social reform after World War II was the nature of the war itself and the overwhelming character of the allied victory.

Conservative adversity, linked to the failure of appeasement and the disarray of the war effort, provided Labour's opportunity. Neville

73 "Trade Unionism and Tariff Reform", London, 17 May 1905, in Charles W. Boyd (ed.), Mr. Chamberlain's Speeches (London, 1914), pp. 324-325.

74 In November $1885 \mathrm{Sir}$ William Harcourt had written that "The rapid conversion of the Tories to Radical measures quickens the speed of Radical progress", Hamer, Liberal Polttics, p. 220. 
Chamberlain's resignation was instigated by Labour's refusal to serve under his leadership in a coalition, and the government that Churchill constituted made two major concessions to labor. First, Churchill committed Britain to total war. Full mobilization required a war effort that made labor indispensable and necessitated close cooperation. Second, after the political revolution of May 1940 Labour staffed most of the key home positions, while Churchill concentrated on the diplomatic and military aspects of the war. ${ }^{75}$

Learning from the failed reconstruction after World War I, a Labour Minister who had participated in the earlier committees, Arthur Greenwood, appointed reconstruction planning commissions, staffed by ardent social reformers, early on in the war. ${ }^{76}$ The most famous of these commissions, chaired by William Beveridge, issued its report in December 1942. Beveridge's report proved invaluable as a program around which Labour and many Liberals could unite.

Nonetheless, "'the most important way in which the war promoted social reform was that it was fought against Fascism and in alliance with Soviet Russia. The relatively high prestige of Soviet Russia during the war raised the stock of planning and Socialism. To boost home front morale, even an inveterate anti-Communist such as Churchill on occasion lauded the USSR. His speech welcoming Russia to the allied cause in 1941 claimed that "I see the ten thousand villages of Russia [ . . .] where maidens laugh and children play." $\pi$

More crucial to reformist success than the Soviet ally, was the disgrace of that substantial section of the right that had sought to appease the Fascists. A good example is the case of Birmingham. Throughout the 1920s, the city had remained true to the heritage of Joseph Chamberlain and loyally supported his sons, Austen and Neville. Opposition to the Unionist party had begun to grow in the late 1920s and the 1930s, but it was only during the war years that the majority of Birmingham's workers turned towards Labour. In 1945, Birmingham was carried by a Labour majority: in this key city, Conservative power was a direct casualty of appeasement.

Labour political leaders took advantage of these chances to remold their political rhetoric to appeal to disgruntled voters; here the motif of "citizenship" emerges. The themes of class solidarity and Socialism, instrumental in keeping the party together during the 1930s, did not

75 James E. Cronin, The Politics of State Expansion: War, State and Society in TwentiethCentury Britain (London, 1991). On the evolution of wartime policy see Stephen Brooke, Labour's War: The Labour Party during the Second World War (Oxford, 1992).

${ }^{76}$ Greenwood had been involved in the planning for reconstruction during World War I and was determined to avoid the problems that caused its failure. See Paul Barton Johnson, Land Fit for Heroes: The Planning of British Reconstruction 1916-1919 (Chicago, 1968).

$n$ Addison, The Road to 1945, p. 134. 
disappear but were joined by a new emphasis on citizenship. A key figure in this new political turn, Herbert Morrison, argued that "Labour [.. .] should nationalize, not in the name of socialist doctrine, but in the name of the community." 78 The citizenship perspective appealed to many middle-class Liberals and, in the field of unemployment and in the whole area of social rights, the Labour Party courted this constituency by adopting wholesale the program of a prominent Liberal; William Beveridge.

The great Labour victory of 1945 in England represented a new political direction for English social policy. Labour had never been a political captive of the wartime coalition, but the extent to which it changed its orientation to take advantage of the circumstances must be stressed. In the field of unemployment, Labour's social policy represented the final break with its traditional demand for the entire funding, of social rights by the state and, following Beveridge, it based its reforms on extending the social insurance principle to the great majority of the nation. In the words of James Griffiths, the first Minister of National Insurance, it was to bring "in everybody from the barrow boy to the field marshal". ${ }^{79}$ Reinforcing and enhancing the social insurance system built around the male wage worker was a new emphasis on a governmental policy of full employment, a combined product of Beveridge's reformism and Keynesian economic thinking, that moved further in the direction of a universal right of citizenship. Already in May 1944, a British Government White Paper on Unemployment recommended that the government accept "as one of their primary aims and responsibilities the maintenance of a high and stable level of employment after the war". 80

Taking up a theme that would soon be given theoretical expression by T.H. Marshall, William Beveridge argued that "If full employment is not won and kept, no liberties are secure, for too many they will not

78 Angus Calder, The People's War: Britain 1939-1945 (London, 1992), p. 533.

7o James Griffiths, Pages from Memory (London, 1969), p. 84. The problem was that it proved impossible to reconcile "bringing everyone in" with Beveridge's other principles, with his plan's commitment to equal benefits for all interruptions of earnings, flat rate payments and flat rate benefits, and a basic subsistence income: José Harris, "Social Planning in War-time: Some Aspects of the Beveridge Report", in War and Economic Development: Essays in Memory of David Joslin (Cambridge, 1973), pp. 239-256. In the end they were not all brought in and those who were not brought in did not receive a subsistence income. Unlike almost every other category of worker, married women who returned to work were not required to contribute and were not paid full benefits if they did. Unmarried mothers were not eligible for insurance benefits, and Beveridge even proposed that separated or divorced women should only be eligible for benefits if the marriage breakdown was in no way their fault: Elizabeth Wilson, Women and the Welfare State (London, 1977), pp. 149-151.

${ }^{80}$ William H. Beveridge, Full Employment in a Free Society (New York, 1945), p.' 260. On Beveridge, José Harris, William Beveridge: A Biography (Oxford, 1977). 
seem worth while." 81 While Beveridge invoked the defense of political liberties to justify his demands for full employment, he, along with many pre-war Liberals, was convinced that full employment was also economically efficient and here he found many Labour party intellectuals who agreed with him. ${ }^{82}$ Armed with both citizenship and efficiency, the new Labour government fully accepted this commitment. ${ }^{83}$ Thus, in the UK, employment was becoming a right of citizenship and the gradual expansion of political citizenship did influence the struggle over social citizenship.

In stark contrast, in France, the growth of political rights did not lead to a substantial broadening of social rights: indeed, in the era of unemployment policy, the expansion of political citizenship was an alternative to the expansion of social citizenship. In France, the division over the legitimacy of the republic, based on both religion and politics, split all groups, particularly employers and the middle classes. As we shall see, this division created serious difficulties for the cause of social reform. If suffrage extension did not promote the enlargement of social rights as Marshall predicted, it was partly because parliamentary democracy in France was not seen as irreversible but as an insecure conquest that needed to be defended.

New political opportunities occurred within the French political order in the years before World War II, but the political disarray within the French working-class movement lessened labor's ability to respond in ways that would promote social reform. And given the lower priority assigned to unemployment by organized workers, it would have required a very successful reform coalition to have enacted this particular type of welfare legislation. As long as French labor was unable to reach out beyond the Radical Socialists, the prospects for social welfare legislation were bleak. In 1906, the secular middle classes rallied behind Dreyfus and provided support for anti-clericalism and the separation of church and state. Politically, they provided the urban political basis for the Radical Socialist Party. Among these urban middle-class radicals, signs of disaffection with laissez-faire certainly appeared in the early twentieth century. The theory of "solidarism" that spread widely among secular republicans, justified state intervention, and roughly parallels the spread of the "new liberalism" among English liberals."

${ }^{81}$ Beveridge, Full Employment in a Free Society, p. 258.

82 See Geoffrey Foote, The Labour Party's Political Thought: A History (London, c. 1985), pp. 173-186.

83 Kenneth O. Morgan, Labour in Power 1945-1951 (Oxford, 1985), p. 138.

so See James T. Kloppenberg, Uncertain Victory: Social Democracy and Progressivism in European and American Thought, 1870-1920 (Oxford, 1986). Kloppenberg is wrong, however, to assimilate the English New Liberalis and French Solidarism to Social Democracy. The differences between the New Liberals and social democracy can be seen most clearly in England, where New Liberals surviving into the mid-twentieth century voted 
Nonetheless, increasingly, in the cities, conservatives and Social Catholics displaced the Radical Socialists whose base shifted from the cities to smallholders in rural France who stood to gain relatively little from social insurance legislation. Moreover, the issue of republicanism remained paramount. Despite the rhetoric of a Herve or a Griffuelhes, both the labor movement and the Socialists were committed to a parliamentary democracy to which the right never became fully reconciled before 1945. The issue of "republican defense" made the working class wholly reliant on the Radical Socialists and prevented the kind of rivalry for the labor vote that occurred in England. The dramatic electoral victory of the left coalition in France in 1906 presents a striking example of this divergence precisely because of its initial similarity to the Liberal landslide of 1906 in Great Britain. In both countries, left/liberal coalitions won substantial victories. But the victories were fought over different political issues and the character of these political battles goes a long way to explain why British political victory resulted in a wave of innovative social reform while the French political victory yielded only political frustration and a deepening of antagonisms between the working-class left and the center-left radicals. In Britain, protectionism was the key issue: Liberal free traders and Conservative protectionists each sought to win labor to their banner by promising to enact social reforms. In France, secularization was the principal issue, and the labor movement could only support republican opposition to clericalism. Although many Social Catholics were more sympathetic to social reform than some Radicals and Radical Socialists, the lukewarm sympathies or the overt anti-republicanism of the Catholic reformers rendered impossible the kind of sustained and close-knit coalition between Catholics and a labor movement that could have produced real sociāl reform. And without needing to worry about working-class defections, Radicals and Radical Socialists could afford the luxury of carrying out attacks on Socialism and repudiating their own electoral program of reform when they involved political sacrifices,

Even the greatest of left-wing political opportunities in inter-war France, the victory of the Popular Front, brought social reform mainly in so far as unionists extracted them from the employers in the Matignon Accords or through executive actions which extended private agreements to other sectors of the economy. Economic historians have lamented the failure to enact the social reform program of the Popular Front, a program that included unemployment insurance, in place of the fortyhour week, won by labor militancy. Yet, electoral studies have suggested that from the beginning there was little possibility that some crucial Radical Socialist members of the Popular Front would have voted to 
enact their own program. The defense of parliamentary government against rightists' attack, the proximate cause for the formation of the Popular Front, in no way provoked a fundamental restructuring of French political life; thus, it bore feeble prospects for enduring reform. Had the workers not acted in June 1936 to take what they could, they might have ended up with nothing at all. ${ }^{85}$

Middle-class reformers, in contrast, played a more limited role than in England or the US because the issue of parliamentarianism created a profound divide within the middle class. Genuinely cross-class coalitions of middle-class social reformers and other social groups were profoundly more difficult to form in France. The middle class rebound from laissezfaire that occurred in the form of solidarism among the secular middle classes also spread among Catholics. A new, more state-oriented "social Catholicism" developed which abandoned the volunteerism and emphasis on private charity so characteristic of early nineteenth-century French Catholicism. Theoreticians of Catholic reform, such as Albert de Mun, were resolutely in favor of state action..$^{86} \mathrm{De}$ Mun, who accepted the ralliement in 1893, sought to elaborate a Catholic social program that could be enacted into law. He drafted the "anti-sweating" legislation that eventually was passed during World War I, and he supported the idea of social insurance, but his anti-republicanism made impossible any sustained cooperation between Social Catholics and republican social reformers. De Mun's defense of social provision owed nothing to the idea of citizenship within the nation-state, but rather belonged to a far older tradition of natural right and human need which saw the Catholic church as the "protectress of the little" and a "mediatrix between the strong and the weak". ${ }^{87}$

For the cause of social reform, the reinforcement of Catholic convictions among the upper middle class presented new possibilities. ${ }^{88}$ The French upper middle class increasingly joined with the aristocracy and rallied to defend clerical schools and institutions against the threat from below, embodied in secular republicanism. ${ }^{89}$ Shut out from the mainstream of French politics by their clericalism, the Catholic middle classes participated all the more fervently in those social reform organizations

8s Paul Warwick, The French Popular Front: A Legislative Analysis (Chicago, 1977).

${ }^{86}$ On early nineteenth-century "social Catholicism" see Katherine Lynch, Family, Class, and Ideology in Early Industrial France: Social Policy and the Working Class Family 18251848 (Madison, 1988) and Robert Talmy, Aux sources de Catholicisme social (Tournai, 1963).

${ }^{87}$ Henri Fontanille, LOeuvre sociale d'Albert de Mun (Paris, 1926), p. 92.

${ }_{88}$ A classic study which shows the similarities of middle-class reformists who were divided by their perspectives on the Church and parliamentary government in the 1930s is JeanLouis Loubet del Bayle, Les non-conformistes des années 30: Un tentative de renouvellement de la pensée française (Paris, 1976).

${ }^{89}$ Ralph Gibson, A Social History of French Catholicism, 1789-1914 (London, 1989), pp. 193-226. 
that did not involve constant contact with republican politicians. For a time, in the 1930s, in the period of the Communist Party's "outstretched hand", some Catholics considered joining the Popular Front coalition. ${ }^{90}$ But Socialist anti-clericalism, the outbreak of the Spanish Civil War, and the firm opposition of the Papacy frustrated these efforts.

Defeat in war and the disgrace of the anti-parliamentary right brought reform-oriented Catholics into the coalition with Socialists and Communists. Between 1945 and 1946, this coalition created a powerful French welfare state. ${ }^{91}$ As in the United Kingdom, only in more extreme form, the French right was discredited by its involvement in appeasement and collaboration. The purge of the French right and a new independence vis-à-vis a discredited church hierarchy cleared the way for reformoriented Catholics who organized politically in the Mouvement Republicain Populaire (MRP). Together, in the two years before the onset of the Cold War broke up the coalition, the moderates in the driving seat of the MRP worked together with the Socialists and Catholics to lay the basis for the modern French welfare state. Had the coalition lasted a few years longer, some form of national unemployment insurance might have been passed. A declaration of October 1945 hinted at the legislature's intention of enacting unemployment insurance. ${ }^{92}$ But its relatively low priority led to a temporary deferment that lasted for ten years when tripartisme collapsed in early 1947. In the area of unemployment benefits, female suffrage which was finally won in 1945 did nothing to awaken the French social system to the needs of an unemployed population that was disproportionately composed of women.

The example of France reveals the problematic nature of the assumption of an immanent relationship between political and social citizenship. There, the very political coalition that extended and defended political rights was an obstacle to the passage of social rights. Between 1890 and 1914 political rights were more extensive in France than in the UK, and yet social citizenship remained retarded. Also, the French case reminds us that there were other claims for building welfare states than those based on citizenship in the welfare state. A number of different coalitions, including coalitions incorporating religious groups and using religious appeals produced welfare reforms. ${ }^{93}$ In the case of unemployment,

90 On the Communist side, see Francis J. Murphy, Communists and Catholics in France, 1936-1939: The Politics of the Outstretched Hand (Gainesville, 1989). Better for the Catholic side is Paul Christophe, 1936: Les catholiques et le Front populaire (Paris, 1986). ${ }^{91}$ The best study of the creation of the French welfare state remains Henry C. Galant, Histoire politique de la sécurité sociale française 1945-1952 (Paris, 1955).

92 Paul Durand, La politique contemporaine de sécurité sociale (Paris, 1953).

'3 A point made, among others, by Arnold J. Heidenheimer, "Secularization Patterns and the Westward Spread of the Welfare State, 1883-1983: Two Dialogues about How and Why Britain, the Netherlands, and the United States have Differed", in "The Wellfare - Statę, 1883-1983", Comparative Social Research, 6 (1983), pp. 3-37. 
issues of citizenship were peripheral to the understanding of the growth of the French welfare state; the character of industrial development, its late but extensive participation in the Second Industrial Revolution, and the nature of French political processes were central.

The Great Depression created the context for new political opportunities in the United States. To some extent, the ability for new groups to mobilize during the crisis can be seen as an outcome of the increased political rights on the part of many more citizens. The result was an extension of social rights such as unemployment compensation for a great many Americans, but such rights still remained a partial benefit.

The most important oppositional forces to state regulated unemployment relief, the corporate community, did not drop their opposition in the immediate aftermath of the Crash and the first waves of wage cuts and layoffs. They accepted President Hoover's approach as he admonished business to hold the line on price and wage cutting while he tried to improve economic conditions by stimulating construction. ${ }^{94}$ But by the end of 1930, a number of corporate leaders were convinced that some sort of stabilization plan was required. Even some leaders active in the US Chamber of Commerce joined with such "New Emphasis" organizations as the National Industrial Conference Board in calling for such plans along the lines of Gerald Swope. In 1930, he had installed a program of unemployment insurance at General Electric and was now calling for a suspension of anti-trust laws so that within trade associations, corporate leaders could develop industry-mandated programs for stabilizing employment and production. ${ }^{95}$ The Rochester Unemployment Benefits plan instituted under Kodak's Folsom, which represented the agreement of fourteen companies to fund an unemployment reserve, was hailed as a vanguard effort on the part of business to create incentives for preventing an increase in unemployment. ${ }^{96}$

Some progressive industrialists were convinced that individual reserve systems, favored by the so-called Wisconsin school of industrial reformers around the AALL, could help act as an incentive to prevent unemployment. ${ }^{97}$ As the Depression deepened, corporate leaders, both progressive and conservative, faced with the continuing problems of financing their own schemes, were anxious both to share the financial burden and to even the competition by mandating programs for all. ${ }^{98}$ When, during

Nelson, Unemployment Insurance, pp. 137-145.

95 See ibid., pp. 141-142; National Industrial Conference Board, Unemployment Benefits and Insurance (New York, 1931), Introduction, part II; see also Colin Gordon, New Deals, Business, Labor and Politics in America, 1920-1935 (Cambridge, 1994), ch. 7.

See ibid., p. 143. See also Jacoby, "Employers and the Welfare State", p. 536.

97 See, for example, the National Industrial Conference Board's endorsement of corporate schemes, and admonition against government programs in the 1931 report, Unemployment Benefits and Insurance, "Summary and Conclusions", pp. 117-127.

${ }_{98}$ See Nelson, Unemployment Insurance, pp. 141-145; Jacoby, "Employers and the Welfare State", pp. 538-541. 
the Presidential campaign of 1932, Hoover dismissed business proposals for economic planning and for at least some prodding on the part of the President, if not the mandating of, corporate financed unemployment reserves, much of the business community refused actively to aid his re-election, while some of the progressives endorsed FDR. ${ }^{99}$ These progressive industrialists, as a number of scholars have noted, played key roles in the early years of the New Deal, first in the planning councils of the NRA, then in the Commerce Department; they were also important in planning the unemployment insurance provision of the Social Security Act of 1935.100

While the business community, weakened by sustained unemployment, was in flux on the question of state-mandated unemployment insurance, so too was organized labor. Faced with mounting unemployment among their membership, the AFL council had, since the late 1920s, endorsed business efforts to stabilize production. As for unemployment benefits, they were still oriented toward individual unions. At the 1930 convention, President William Green warned that any system of mandated unemployment insurance would force union members to take non-union jobs. ${ }^{101}$ But the AFL leadership was not able to determine the activities of its constituent unions on the local level and many were involved in a variety of calls for greater public relief. Left-wing unions involved in the Conference for Progressive Labor Action campaigned for full-scale government insurance. ${ }^{102}$ In 1930, the more traditional International Association of Machinists joined with a number of progressive AFL unions - the garment unions, textile workers and teachers - in calling for unemployment insurance. The early 1930s also saw a wave of local and labor council endorsements for the idea of compulsory unemployment insurance along with local and state councils in such strong labor states as New York, Pennsylvania, Wisconsin and Ohio, where unions became a key factor in the state battle for unemployment insurance.

By 1935, thousands of labor locals and some thirty-three labor union councils, including Pittsburgh and Queens County, NY, had endorsed the Workers Unemployment and Social Insurance Bill, which called for an immediate establishment of a system of unemployment insurance for all workers and farmers. ${ }^{103}$ Originally put forward by leftist New York union locals forming the AFL Trade Union Council for Unemployment

99 See Nelson, Unemployment Insurance, pp. 142, 143.

100 See ibid., p. 143; Jacoby, "Employers and the Welfare State", p. 538; Fraser, Labor Will Rule, ch. 10.

${ }^{101}$ Nelson, Unemployment Insurance, p. 155.

102 See ibid., p. 156; Fraser, Labor Will Rule, p. 278.

${ }^{203}$ See Kenneth Casebeer, "The Worker's Unemployment Insurance Bill: American Social Wage, Labor Organization, and Legal Ideology", in Christopher L. Tomlin and Andrew J. King, Labor Law in America: Historical and Critical Essays (Baltimore, 1990), pp. 231259 , especially pp. 232 and 245; David Montgomery, "Labor and the Political Leadership of New Deal America", International Review of Social History, 39 (1994), pp. 348-349. 
Insurance and Relief, it was introduced as a bill in the US House of Representatives in 1934 by Minnesota Representative Ernest Lundeen of the Farmer-Labor Party. Though the bill was defeated in the House, it represented important left-wing pressure on the government and on American unions during the formative years of the Social Security Act, as well as other national labor legislation. ${ }^{104}$

At its 1932 convention, the AFL leadership finally endorsed a lukewarm resolution in favor of unemployment insurance, but it hardly mattered. ${ }^{105}$ The center of influence shifted to labor leaders like Sidney Hillman who were in a position to exert political power as a member of FDR's left coalition. Once the Depression hit, Hillman was making common cause with reformers of the AALL in pushing for state legislation on unemployment in New York. By 1932, he was serving as an advisor to Governor Roosevelt and State Labor Commissioner Frances Perkins regarding unemployment insurance in New York state. ${ }^{106}$ Recent analyses of labor and the New Deal have emphasized labor's inability to influence the outcome of the 1935 Social Security Act. ${ }^{107}$ The labor wing of President Roosevelt's coalition, however, as we shall see, was positioned to exert some influence on the outcome of the unemployment provisions of that legislation.

But many other Americans struggling with unemployment were unable to exert any influence and the resulting legislation reflected their weakness. Here, Marshall's important connection between political rights embodied in citizenship, and social rights is relevant, but in a limited way. At the height of agitation for unemployment relief, leftists stressed that their inclusive politics was different from the traditional AFL exclusionary approach, with its very limited definition of the citizenry. Thus, in their preamble to their Constitution, the Pittsburgh Unemployment Citizens' League noted in 1934 that: "by citizen we do not mean only those persons who are naturalized but all wage-earners. We give no aid or comfort to profiteers, the prophets of nationalism or to those who seek to divide the worker on grounds of race or sex. Therefore by citizen we mean citizen of the working class as contrasted with citizen of the ruling class. We believe that the worker should have an international outlook and that his aim should be cooperation with workers in other lands rather than with the ruling class where he happens to live." 108

${ }^{104}$ See Casebeer, "The Worker's Unemployment Insurance Bill”, pp. 238, 248.

${ }^{105}$ Nelson, Unemployment Insurance; Lubove, The Struggle, p. 171.

106 Fraser, Labor Will Rule, pp. 273, 274.

107 See Montgomery, "Labor and the Political Leadership", pp. 347-353; Gordon, New Deals, ch. 7. For recent interpretations which conclude that labor was able to influence and benefit from New Deal legislation in meaningful ways, see Melvyn Dubovsky, The State and Labor in Modern America (Chapel Hill, 1994); Lisabeth Cohen, Making a New Deal: Industrial Workers in Chicago; $1919-1939$ (Cambridge, 1990).

108 "Constitution and Platform: Unemployed Citizens' League of Allegheny County", preamble, p. 2 (Archives of Industrial Society, University of Pittsburgh). 
But, in fact, to the extent that Hillman and others in FDR's labor coalition, who worked with New Deal administrators to fashion the unemployment pensions of the Social Security Act, could succeed at all, it was as representatives of a new political power - the votes of many who had been immigrants, but were now voting American citizens. ${ }^{109}$ And moving beyond Marshall, this history suggests that political rights only achieve social rights when they can be translated into political power. Unions provided new Americans with greater political rights because they could mobilize large blocs of votes. In that context labor could exert some minimal guarantees in the face of a number of powerful interests - such as business, Southern agrarians, etc. - determined to minimize state relief. Not only those large numbers of African-Americans not empowered to vote, but enfranchised Americans (including many women, minorities and poor whites) not organized through the union to exert political power, were, in fact, left out of the guarantees to unemployment insurance as it was written in the 1935 Social Security law. The law was designed to appease those who were politically powerful, the corporate community, agrarian capitalists, white Southern elites, and, to some extent, organized labor; it thus excluded coverage of many.jobs dominated by female and African-American labor. ${ }^{110}$

The needs of the business community, the cry on the part of local and state governments, stretched to the limit in terms of their own relief

109 Along these lines it is important to note, as Kenneth Casebeer points out, that the only substantive difference between the Trade Union Councils radical insurance bill and the version introduced in Congress by Lundeen was that, in the Congressman's version, workers benefits were limited to American citizens. "The Workers Unemployment Insurance Bill", p. 248.

${ }^{110}$ On the discriminatory effects of unemployment insurance policy as it was embodied in the Social Security Act see, among others, Barbara Nelson, "The Origins of the Two-Channel Welfare State: Workmen's Compensation and Mothers' Aid", in Linda Gordon (ed.), Women, the State and Welfare (Madison, 1990), pp. 123-151 and Diana M. Pearce, "Toil and Trouble: Women Workers and Unemployment Compensation", Signs, 10 (Spring 1985), pp. 439-459. Alice Kessler-Harris has recently shown that the Social Security Amendments of 1939, which provided pension benefits for widows, were designed to reinforce traditional gender roles, with additional money being rewarded to mostly white, male pensioners, to cover their wives in widowhood, rather than through extended greater benefits to female wage earners, or, for that matter, by broadening the categories of workers covered by social security in the jobs heavily dominated by women and minorities. See "Designing Women and Old Fools: The Construction of the Social Security Amendments of 1939", in Linda Kerber, Alice Kessler-Harris and Kathryn Kish Sklar (eds), U.S. History as Women's History: New Feminist Essays (Chapel Hill, 1995), pp. 87-104. While Kessler-Harris argues that this is evidence of the way in which gendered policies were used not as a surrogate for class, as Kathryn Sklar has argued (see "Two Political Cultures", in U.S. History As' Women's History, p. 41), but as a vehicle for weakening efforts to broaden coverage of the working class and of minorities. One could argue that class power still remained salient, since those who reaped the benefits were the families among organized labor, along with others covered by social security pensions. In European countries, with stronger class movements, widows' pensions were handled in the same manner - by increasing benefits of married men to cover their wives. 
reserves, and the growing power of the labor movement, meant that the New Deal years provided a most opportune moment for American reformers long interested in government mandated legislation. But we ought not to overemphasize the importance of reformers in understanding the enactment of unemployment insurance in 1935. Theda Skocpol explains the failures of social insurance during the earlier decades of the century by focusing on the particular convictions of middle-class reformers, which did not mesh well with the American state structure. Middle-class reformers abhorred a patronage system which was so endemic to the United States' political structure, but they could not put into place a large government of professional civil servants to carry out reform, because the US lacked a traditional state bureaucracy. ${ }^{111}$ Our work suggests this analysis puts too much emphasis on the convictions of reformers in explaining the shape of the welfare state. When in the mid-1930s some opportunity for success regarding unemployment insurance was at hand, both academic activists outside government, and reformers now in the New Deal, understood that, ultimately, a number of cherished beliefs would have to be abandoned because policy "wonks" were in the driver's seat only so far as they could help put together a coalition of those who were in a position to bargain - i.e. those who could wield power by mobilizing others.

That policy reformers could play only a limited role in determining outcomes was becoming increasingly clear in the state-wide campaigns for unemployment insurance, which took place in the early and mid1930s. The Wisconsin Plan, enacted in 1932, which called for both employer/employee contributions and the maintenance of individual corporate reserves, rather than a pooled fund, well reflected the commitment of a number of middle-class activists such as John Andrews, Elizabeth Brandeis and her husband Paul Raushenbush; they believed it was important to maintain individual reserves as an incentive for corporations to limit laying off workers, and to make workers contribute to their unemployment fund. ${ }^{112}$ In Wisconsin, they could mobilize opinion Brandeis and Raushenbush heavily financed the campaign - to fashion such an outcome. ${ }^{113}$ But they were unable to replicate those basic elements in Ohio in 1936, where, backed by a strong Cleveland Federation of Labor, the bill embodied some of the most formidable challenges to the progressive business model of Wisconsin. In Ohio contributions came solely from employers, and unlike Wisconsin, with its emphasis on the individual corporation's ability to prevent unemployment, all reserves were pooled into a single state fund, so that employer risks

"11 Skocpol, Protecting Soldiers and Mothers, especially part 2 and the Conclusion.

112 See ibid., part 2. See also Lubove, The Struggle; Nelson, Unemployment Insurance, ch. 6 .

${ }^{113}$ See ibid. 
were spread out. In New York, a strong labor commitment insured that funds would be pooled and the bill, originally passed in 1935, required no employee contribution. Finally, the strength of the labor movement in Pennsylvania was made clear in the provisions of their state unemployment insurance bill, passed in 1936, which provided for pooled funds, no employee contributions, relatively wide coverage and strong assurances for the rights of organized labor. ${ }^{114}$

On the national level as well, because the outcome of legislation could only be determined by bargaining between powerful interests, reformers were either forced to conform to the parameters of the discussion, or be left out of the process. In fashioning her Committee on Economic Security to flesh out the Social Security bill, and in the effort to drive it through Congress, Secretary of Labor Perkins invited into the process those with whom she knew she would have to deal, from business, farming and labor, but, from among her fellow middle-class reformers, she excluded those on the "left", such as Isaac Rubinow and Abraham Epstein. They had remained committed, on principle, to a federallystandardized program of social insurance which would have been much more universal, but beyond the limits of possibility in a bill designed to get through the US Congress. ${ }^{115}$ Perkins also excluded from deliberations Brandeis and Raushenbush, on the "right", because they were unwilling to bend in their commitment to the Wisconsin plan of individual business reserves as the model for the whole nation. ${ }^{116}$ Perkins and her chief assistant for Social Security, Edwin Witte, knew that among other things organized labor would not stand for such a position.

In the end, the unemployment insurance feature of the Social Security Act became essentially a program of federal incentives for state-run unemployment insurance programs which followed certain general guidelines. The bill provided a little something for a few constituencies. The progressive business community involved in negotiating got a lot of what they wanted, the possibility that states could implement the more conservative Wisconsin, rather than the Ohio plan, and many exemptions in terms of coverage. But labor extracted something as well; despite business desires for mandated employee contributions, the final bill left the contribution system up to state option, insuring the possibility that they could enact the Ohio Plan. And the Ohio approach ultimately dominated. By 1940, only five of the forty-eight states, all with unemployment compensation programs, levied taxes on workers as well as

114 Commonwealth of Pennsylvania, Department of Labor and Industry, Unemployment Compensation Law, 1 December 1938; Josephine Van Fleet, "An Appraisal of the United States-Pennsylvania Unemployment Compensation Program" (M.A., University of Pittsburgh, 1938), pp. 2, 3; Nelson, Unemployment Insurance, pp. 189, 190.

115 See Nelson, Unemployment Insurance, ch. 9; Lubove, The Struggle, Conclusion.

116 Nelson, Unemployment Insurance, p. 209. 
employers. ${ }^{117}$ The American response to unemployment thus extended entitlement, but unemployment relief still remained a partial right, because many people who badly needed benefits either had no political rights, or, perhaps most important, political rights, but no political power.

\section{CITIZENSHIP, UNEMPLOYMENT AND SOCIAL POLICY TODAY}

How does our comparative analysis of the struggle over unemployment policy bear on T.H: Marshall's conclusions about the expansion of citizenship rights and on current efforts to develop a politics of citizenship for the modern industrial world? Answering this question has acquired a new urgency, since many sociologists and political scientists have recently begun to use Marshall's analyses as a constitutive element in their own efforts to argue for a new political rhetoric based on citizenship. Our histörical study provides little support for the belief that a single-minded reliance on citizenship, as implied in the "radical democracy" proposáls, will prove successful in orienting political action today. While almost all modern scholars allow for a larger role for social conflict than Marshall, they center their analyses on the alleged ability of citizenship to create a sense of common purpose and solidarity among widely disparate groups. Some of these scholars, such as Ernesto Laclau, Chantal Mouffe and Stanley Aronowitz argue for the need to recast the existing Socialist left along the lines of "radical democracy" in which citizenship will provide a measure of unity for "new social movements". ${ }^{118}$ Others such as Herbert Kitschelt have argued that existing Social Democratic parties should adopt a more "communitarian" approach and advocate a citizenship with "libertarian objectives and market effici-

${ }^{117}$ National Resources Planning Board, Security, Work and Relief Policies (Washington, 1942), p. 70. Marion Folsom was dismayed to discover that in New York, Kodak would have to live under conditions closer to the Ohio scheme, rather than the more businessoriented Wisconsin plan. See Jacoby, "Employers and the Welfare State"; p. 541.

${ }^{118}$ Ernesto Laclau and Chantal Mouffe, Hegemony and Socialist Strategy: Towards a Radical Democratic Politics (London, 1985); Chantal Mouffe (ed.), Dimensions of Radical Democracy: Pluralism, Citizenship, and Community (London, 1992) and Chantal Mouffe, The Return of the Political (London, 1993). See also Stanley Aronowitz, "The Situation of the Left in the United States", Socialist Review, 23 (1993), pp. 5-80, and the responses to these, particularly those by Ehrenreich, Epstein, Flacks and Zaretsky. Scholars who have been influenced by Marshall include: James F. Hollifield, Immigrants, Markets and States; The Political Economy of Postwar Europe (Cambridge, MA, 1992); Claus Offe, "A Non-Productivist Design for Social Policies", in Harry Coenen and Peter Leisink (eds), Work and Citizenship in the New Europe (Cambridge, 1993), pp. 215-232; Maurice Roche, Rethinking Citizenship: Welfare, Ideology and Change in Modern Europe (Cambridge, 1992); and Bryan Turner, Citizenship and Capitalism: The Debate over Reformism (London, 1986). 
ency". ${ }^{119}$ Although all these arguments vary at points, they agree in portraying an ideology of citizenship as key in forging new political identities and as exerting a powerful independent role in the shaping of social rights.

Certainly, the rhetoric of citizenship has served in the past and will serve in the future to promote the formation of coalitions among disparate groups. But it is the specific character of coalitions that concerns most political analysts, and a number of the theorists of citizenship ignore the constraints that give the rhetoric of citizenship its content. For Mouffe, the goal is to "construct a 'we' as radical citizens, a collective political identity [. . .]" based on a shared political commitment to end all forms of domination experienced by various groups, such as "women, workers, blacks, gays, etc.". ${ }^{120}$ Such a vague aspiration underestimates the need for shared agreement on political tactics and priorities and neglects economic and social forces that have been basic to the battle for social rights. ${ }^{121}$ We have less quarrel with those, such as Kitschelt, who see "citizenship" as only one constitutive element of Social Democratic policy committed to social equality but warn that, in some European countries, it may prove a dangerous weapon.

Marshall's emphasis on social solidarity directs attention away from the mobilization and political crises, the conflicts and coalitions, that have been the real progenitors of social rights. Unemployment policy has been deeply entangled in the politics of labor markets, and it seems unlikely that it will free itself from these constraints. Furthermore, at every stage, organized groups played a crucial role in the formation of social welfare policy. None of the groups involved in the struggle over unemployment policy represented unchanging and ahistorical interests that could be deduced a priori or out of context; their willingness to permit or to lobby for government intervention in social policy was strongly influenced by changing social and political conditions. Before the high and sustained unemployment of the 1880s, British trade union leaders had been unsympathetic to unemployment pensions and, during the golden years of the mid-century, British employers would never have tolerated government intervention in regulating labor. Nor would trade unionists or employers have considered government intervention seriously without the breakdown of established political stability which made it possible to contemplate momentous changes in social policy.

${ }^{119}$ Herbert Kitschelt, The Transformation of European Social Democracy (Cambridge, 1994), p. 300.

${ }^{130}$ Mouffe, "Feminism, Citizenship and Politics", in The Return of the Political, p. 84.

121 Anna Clarke also critiques Mouffe. Discourses do not determine politics, according to Clark, but, rather, power relations and political goals, such as the maintenance of male dominance, determine the kind of politics of discourse chosen by those putting forth political demands. See Clarke, The Struggle for the Breeches: Gender and the Making of the Working Class, 1790-1840 (Berkeley, 1995), p. 9. 
We argue that the expansion of suffrage aided the cause of social rights in so far as it facilitated the mobilization of groups fighting for social rights. In England, suffrage expansion, by allowing more workers to vote, was a powerful force in giving the Labour Party predominance on the left. In France large numbers of workers mobilized to defend their political rights, but social reform could not be enacted so long as the republic itself was in jeopardy. In the United States easy access to the suffrage for white males and then females made it possible for recent migrants to enter the political arena and gain some measure of political power.

But sheer ability to mobilize does not guarantee political achievement, and suffrage expansion was only one element in the battle for social rights. Universal suffrage did not bring about a generalized social solidarity. Between 1890 and 1950 , only some groups within the newly enfranchised population substantially increased their level of mobilization, usually those groups that were already the more mobilized. Furthermore, the timing, the impact and the scale of mobilization among new groups was influenced by the existence of conflicts within the social order that might lead a powerful political group to sponsor and protect the newly mobilizing group.

As a result of the uneven character of mobilization, universal suffrage has never benefited all the newly enfranchised. In the struggle over unemployment policy in the period under study and in all three countries, the plight of married women was typically ignored. In the United States, blacks benefited less than ethnics from the New Deal reforms. Even though women and northern blacks possessed the vote, their weak organization, combined with sexism and racism within existing institutions led political decision-makers to relegate their claims to a low priority. ${ }^{122}$ These outcomes cannot be attributed solely or even principally to the lack of consciousness of political leaders. They are also constrained by the availability of allies and the extent of group mobilization.

The point to be underlined here, one that Marshall largely ignored, is that political rhetoric must be linked integrally to political strategy. While an inadequate political rhetoric has, on occasion, limited the accomplishments of political leaders and social movements, in the long run the failure to consider fully the possibilities for mobilizing new groups, for more extensively mobilizing existing groups and for making the most of political opportunities have been far more constraining.

Plausible and coherent political rhetorics are important, but appeals to religious obligation, national economic self-interest, proletarian internationalism, social imperialism, humanitarianism and citizenship have all

122 The most complete discussion of how these factors combined to leave women vulnerable in the construction of social security benefits can be found in Linda Gordon, Pitied But Not Entitled: Single Women and the History of Welfare (New York, 1994), chs 7-9. 
been used to extend social rights. Doubtless such a mélange of moral appeals will continue to drive social reformers and to rally diverse groups to the cause of reform. In specific circumstances, some appeals have proved more effective than others. In England in the period of our study, the political rhetoric of citizenship played a significant role. In 1942 William Beveridge played a pivotal role in articulating a rhetoric of citizenship that brought different groups together behind concrete social reforms. The decision of the Labour Party to swing behind Beveridge's program indicated to many middle-class voters that Labour was responsive to their needs. But we should also note that the appeals of citizenship in England occurred in a very special context of a country which had a tradition of out-migration and whose largest group of immigrants, the Irish, had been granted full citizenship. ${ }^{123}$

But if citizenship has at times played a role in the fight against unemployment, we are less sanguine about its modern-day potentialities for building social movements in some European countries. Persistent levels of unemployment in Europe as well as in the United States, have given rise to new attacks on immigrant populations and new laws limiting migration. Traditionally, in the area of unemployment, the rhetoric of citizenship has been used against those who refuse to seek exclusive membership in one national community or who are unable to meet the requirements for admission to a national community. Some hope to use appeals for European rights and European citizenship, as a way to protect migrants' rights in individual European countries. Indeed, rulings of the European Court of Justice have opened up such possibilities. ${ }^{124}$ But there are disadvantages as well as advantages in raising issues in this manner. Many of Europe's migrant population, especially that permanently established foreign population that Hammer labels "denizens", do not consider themselves to be Europeans; they do not apply for naturalization, seen as the first step in assimilation. ${ }^{125}$ Particularly in those countries of Europe with a large migrant population that face the prospect of further migration from Eastern Europe, there may be considerable dangers in the citizenship approach. Racism and chauvinism, which many have pointed to as characteristic of the American white working class, have, of late, grown among native European workers faster than anyone might have anticipated only a few years ago. Further, long-time resident migrant workers have been, for some time now, an increasingly militant and politically active section of the labor force. ${ }^{126}$

${ }^{123}$ On migration to England from the Irish Republic, see Kathleen Paul, "A Case of Mistaken Identity: The Irish in Post-War Britain", International Labor and Working-Class History (forthcoming).

${ }^{124}$ See Elizabeth Meehan, Citizenship and the European Community (London, 1993).

125 Tomas Hammar, Democracy, and the Nation State: Aliens, Denizens and Citizens in a World of International Migration (Aldershot, 1990).

${ }^{126}$ See Mark J. Miller, Foreign Workers in Western Europe: An Emerging Political Force (New York, 1981). 
And even if appeals to citizenship do help the "denizen" population, they are almost certain to disadvantage those most recent migrants from Eastern Europe who do not have the claims of long residence. ${ }^{127}$

In conclusion, we believe that a serious effort to rethink left-wing politics must address other issues than those of political rhetoric. At the level of rhetoric, an emphasis on universal human rights might be preferable to the language of citizenship. ${ }^{128} \mathrm{But}$ at its best, political rhetoric can aid political analysis and relate political appeals to other aspects of politics, such as suggesting new groups that may be mobilized or themes that may deepen the mobilization of existing organizations, or the possibilities of cooperating with other groups. At least in their existing form, most arguments that center on citizenship do not adequately address these issues.

${ }^{227}$ Thomas Faist, "Transnationalizing Labor Markets and Social Rights in Europe", unpublished paper delivered at the conference on "Markets, States, and Social Citizenship: European Economic and Political Integration, 1900-1955", New School for Social Research, New York, May 1994.

${ }^{128}$ See Yasemin Nuhoglu Soysal, Limits of Citizenship: Migrants and Postnational Membership in Europe (Chicago, 1994). 